\title{
Bipolar Disorder Management Physician Oder: New Initiatives at the Mental Hospital of Ministry of Health in Saudi Arabia
}

\author{
Yousef Ahmed Alomi*1, Nora Alsolami ${ }^{2}$, Nada Alqahtani ${ }^{3}$, Abeer Alsairi ${ }^{4}$, Ban Aldossari ${ }^{5}$ \\ ${ }^{1}$ The Past General Manager of General Administration of Pharmaceutical Care and Past Head, National Clinical pharmacy, \\ pharmacy practice and Pharmacy $R \& D$ Administration, Ministry of Health, Riyadh, KSA \\ ${ }^{2}$ Head, Pharmaceutical Care Services, Al-Amal Medical Complex, Ministry of Health, P.O.BOX 100, Riyadh, Saudi Arabia. \\ ${ }^{3}$ Head, Drug Information Services, Pharmaceutical Care Services, Al-Amal Medical Complex, Ministry of Health, P.O.BOX 100, \\ Riyadh, Saudi Arabia. \\ ${ }^{4}$ Head, Medication Safety Officer, Pharmaceutical Care Services, Al-Amal Medical Complex, Ministry of Health, P.O.BOX 100, \\ Riyadh, Saudi Arabia. \\ ${ }^{5}$ Head, Inpatient Pharmacy, Pharmaceutical Care Services, Al-Amal Medical Complex, Ministry of Health, P.O.BOX 100, Riyadh, \\ Saudi Arabia.
}

Received: 07 March 2018;

Accepted: 11 May 2018

*Correspondence to:

Dr. Yousef Ahmed Alomi,

The Past General Manager of General Administration of Pharmaceutical Care Head, National Clinical pharmacy, and pharmacy practice Head, Pharmacy $R$ and $D$ Administration Ministry of Health, P.O.BOX 100, Riyadh 11392, Riyadh, SAUDI ARABIA. Email:yalomi@gmail.com

Copyright: (C) the author(s),publisher and licensee Indian Academy of Pharmacists. This is an open-access article distributed under the terms of the Creative Commons Attribution Non-Commercial License, which permits unrestricted non-commercial use, distribution, and reproduction in any medium, provided the original work is properly cited.

\begin{abstract}
The national psychiatric pharmacy program is new system founded in the Kingdom of Saudi Arabia. The program of mental health care services at Ministry of health. The new program started with several initiatives projects including evidence named medicine guidelines. The new project of bipolar disorder management physician order was one the outcome of the program. The guidelines development through task force committee by Pharmacy department at the most prominent mental hospital, in Riyadh region in Saudi Arabia. The project prevents antipsychotic-related problems and avoids the unnecessary economic burden on the healthcare system. The new initiative's project is new in Saudi Arabia, Gulf and Middle East counties.
\end{abstract}

Key words: Bipolar Disorder, Management, Physician Oder, Ministry of Health, Saudi Arabia.

\section{INTRODUCTION}

The psychiatric healthcare services are expanding over the past several years in Kingdom of Saudi Arabia. ${ }^{[1]}$ That has included the numbers of hospitals, number of beds and all supportive services including psychiatric pharmacy practice. ${ }^{[1-3]}$ The pharmacy department of the Mental hospital Ministry of Health in Riyadh region implemented several programs and services. It included patient education program, drug information services, and evidencebased medicine guidelines. Recently the mental hospital implemented new initiatives project of bipolar disorder management physician order. Several studies showed the benefit of psychiatric management guidelines. ${ }^{[4-6]} \mathrm{It}$ improves patient outcome and prevents drug-related errors. The psychiatric mental health care system missed those guidelines in Saudi Arabia. Also, it seldom to find this project at Gulf or Middle East counties. The goal of the mini-review to explore the bipolar disorder treatment physician order at a Mental hospital in Kingdom of Saudi Arabia.

Bipolar disorder Therapy order in Saudi Arabia

The bipolar disorder management physician order form consisted of patient demographic data, the type or stage of disease, the first line of treatment, the dose and duration of therapy, the second line of choice if existed. The comorbid disease with primary disease and appropriate choice for each combined disease. The prescribed data and clinical pharmacist data as explored in the physician order form. The form can quickly convert to the electronic format in the computer pharmacy system as explored in appendix 1.

\section{SWOT Analysis}

The SWOT analysis used for the project. The strong points of the project were a clinical pathway of psychiatric management, educational tool for new staff; it fit the accreditation and requirements of national organizations of accreditation health care institutions, it is control of hospital formulary and prevents miss-use if medications. The forms not covered all psychiatric disease, it is not contained all antipsychotic medications, it was not an electronic format. The opportunities points were part of accreditation requirements, and threads points were it not followed by healthcare staff, the new updating of the therapeutic guidelines. 
Implementations steps of Bipolar disorder management physician Oder

It is evidence-based setting up psychiatric therapeutic guidelines at biggest hospital a mental hospital at Ministry of Health in Kingdom of Saudi Arabia. The guidelines based on evidence based on American psychiatric society recommendations. It designed through pharmacy task force team and headed by the author. The team consisted of head of pharmacy, drug information pharmacist, four clinical pharmacist at acute and ambulatory care services, and medications safety office and inpatient and outpatient supervisor. The team divided into several three groups. Each group made different therapeutic management guidelines of common disease depression, schizophrenia and bipolar dossiers. The first draft finished by the teams then covered as physician order format by the first author. The therapeutic physician order revised by the three groups. The team made several discussion and final agreement. The head of pharmacy submit to the pharmacy and therapeutic for final approval. The psychiatric therapeutic physician order approved by the committee after several discussion and meeting. The guidelines implemented through several education session with hospital staff. The manual physician order sent to information technology to convert as electronic physicians order entry.

\section{CONCLUSION}

The new initiative's project of bipolar disorder management physician order had several advantages for patients and healthcare services in Saudi Arabia and first services in Gulf and Middle East counties.

\section{ACKNOWLEDGMENT}

None.

\section{CONFLICT OF INTEREST}

None.

\section{ABBREVIATIONS}

None.

\section{REFERENCES}

1. Qureshi NA, Al-Habeeb AA, Koenig HG. The mental health system in Saudi Arabia: An overview. Neuropsychiatr Dis Treat. 2013;9(1):1121-35.

2. Koenig HG, Zaben F Al, Sehlo MG, Khalifa DA, Shaheen M, Ahwal A, et al. Mental Health Care in Saudi Arabia: Past, Present, and Future. Open J Psychiatry. 2014;4(2):113-30.

3. Almutairi AF. Mental illness in Saudi Arabia: An overview. Psychol Res Behav Manag. 2015;8:47-9.

4. Katon W, Korff M Von, Lin E, Walker E, Simon GE, Bush T, et al. Collaborative Management to Achieve Treatment Guidelines. JAMA. 1995;273(13):1026.

5. Citrome L, Yeomans D. Do guidelines for severe mental illness promote physical health and well-being? J Psychopharmacol. 2005;19(6):102-9.

6. Niederkrotenthaler T, Sonneck G. Assessing the Impact of Media Guidelines for Reporting on Suicides in Austria: Interrupted time Series Analysis. Aust New Zeal J Psychiatry. 2007;41(5):419-28.

Cite this article as: Alomi YA, Alsolami N, Alqahtani N, Rahbini A. Bipolar Disorder Management Physician Oder: New Initiatives at the Mental Hospital of Ministry of Health in Saudi Arabia. J Pharm Pract Community Med. 2018;4(2):124-5. 


\begin{tabular}{|c|c|c|c|c|}
\hline 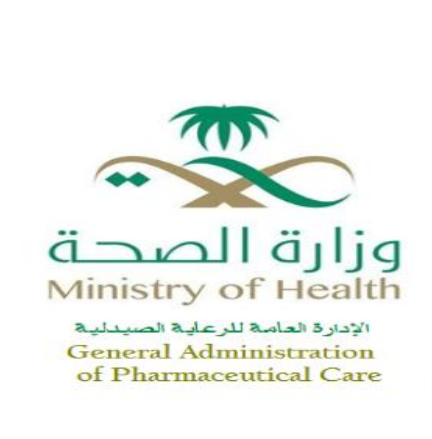 & \multicolumn{3}{|c|}{$\begin{array}{l}\text { Pharmaceutical Care Department } \\
\text { Riyadh Region } \\
\text { Physician Order Form } \\
\text { lease fill all applicable information and stick it on } \\
\text { ient profile, and forward the copy to the Pharmacy } \\
\text { Department within } 24 \text { hrs) }\end{array}$} & $\begin{array}{l}\text { FILE NO: } \square= \\
\text { NAME: }\end{array}$ \\
\hline \multicolumn{5}{|c|}{ Adult Bipolar disorder management(1)(2)(3) } \\
\hline $\begin{array}{l}\text { Diagnosis: } \\
\ldots \ldots \ldots \ldots \ldots \ldots \ldots \ldots \ldots \ldots \ldots \ldots \ldots \ldots \ldots \ldots \ldots \ldots \\
\ldots \ldots \ldots \ldots \ldots \ldots\end{array}$ & ia or hypomani & & & \\
\hline Condition & Dose & Therapy & & Comments $(1)(4)(5)$ \\
\hline \multirow[b]{2}{*}{$1^{\text {st }}$ Choice } & $1 \ldots \ldots \ldots \ldots$ & Lithium & $\begin{array}{l}\text { (usua } \\
-I R: 60 \\
-X L: 1 \\
\text { Maxin }\end{array}$ & $\begin{array}{l}\text { erapeutic serum } 1-1.5 \mathrm{mmol} / \mathrm{L}) \text {. } \\
\mathrm{ng} 3 \text { times a day } \\
\mathrm{mg} \text { in } 2-3 \text { divided doses /day } \\
\mathbf{n} \text { dose: } 1800 \mathrm{mg} / \text { day OR }\end{array}$ \\
\hline & $2 \ldots \ldots \ldots \ldots$ & Na Valproate & $\begin{array}{l}\text { IR:750 } \\
\text { as quic } \\
\text { effect; } \\
\mathrm{mcg} / \mathrm{m} \\
\text { Maxi } \\
\text { XL: } 25 \\
\text { quickl } \\
\text { target } \\
\text { mcg/m } \\
\text { Maxin }\end{array}$ & $\begin{array}{l}\text { g orally per day in divided doses; increase } \\
\text { y as possible to achieve desired clinical } \\
\text { rget trough plasma level was } 50 \text { to } 125 \\
\text { ( } 347 \text { to } 867 \mathrm{mcmol} / \mathrm{L} \text { ) in studies; } \\
\text { um dose: } 60 \mathrm{mg} / \mathrm{kg} / \text { day } \\
\text { g/kg/day orally once daily; increase as } \\
\text { s possible to achieve desired clinical effect; } \\
\text { bugh plasma level range was } 85 \text { to } 125 \\
\text { (590 to } 867 \mathrm{mcmol} / \mathrm{l} \text { ) in studies; } \\
\mathbf{m} \text { dose: } 60 \mathrm{mg} / \mathrm{kg} / \text { day }\end{array}$ \\
\hline \multirow{2}{*}{$\begin{array}{c}2^{\text {nd }} \text { Choice (Add to mood } \\
\text { stabilizer) }\end{array}$} & $1 \ldots \ldots \ldots \ldots$ & Aripiprazole & $\begin{array}{l}15 \mathrm{mg} \\
\text { OR }\end{array}$ & ay increasing up to $30 \mathrm{mg} /$ day as required \\
\hline & $2 \ldots \ldots \ldots \ldots$ & Olanzapine & $10 \mathrm{mg}$ & ay increasing to $15 \mathrm{mg}$ or $20 \mathrm{mg}$ as required \\
\hline \multirow{2}{*}{$\begin{array}{c}3^{\text {rd }} \text { Choice (Add to mood } \\
\text { stabilizer) }\end{array}$} & $1 \ldots \ldots \ldots \ldots$ & Risperidone & \multicolumn{2}{|c|}{2 or $3 \mathrm{mg} /$ day increased to $6 \mathrm{mg} /$ day as required } \\
\hline & $2 \ldots \ldots \ldots \ldots$ & Quetiapine & \multicolumn{2}{|c|}{$\begin{array}{l}\mathrm{IR}-100 \mathrm{mg} / \text { day increasing to } 800 \mathrm{mg} / \text { day as } \\
\text { required. Higher starting doses have been used. } \\
\mathrm{XL}-300 \mathrm{mg} / \text { day increasing to } 600 \mathrm{mg} / \text { day on day } 2\end{array}$} \\
\hline
\end{tabular}

Treatment of bipolar depression:

\begin{tabular}{|c|c|c|c|}
\hline Condition & Dose & Therapy & \multicolumn{1}{c|}{ Comments } \\
\hline & $1 \ldots \ldots \ldots \ldots .$. & $\begin{array}{l}\text { Olanzapine }+ \\
\text { Fluoxetine }\end{array}$ & $\begin{array}{l}\text { Start with } 5 \mathrm{mg} \text { Olanzapine+ fluoxetine 20 } \mathrm{mg} \\
\text { ORALLY once daily each evening; may adjust dose for } \\
\text { efficacy and tolerability within range of olanzapine } 5 \\
\text { to } 12.5 \mathrm{mg} \text { and fluoxetine } 20 \text { to } 50 \mathrm{mg}\end{array}$ \\
\cline { 2 - 4 } & $2 \ldots \ldots \ldots \ldots$ & Quetiapine & $\begin{array}{l}\text { IR: } 50 \mathrm{mg} \text { orally once daily on day } 1 ; 100 \mathrm{mg} \text { once } \\
\text { daily on day 2; } 200 \mathrm{mg} \text { once daily on day 3; and }\end{array}$ \\
\hline
\end{tabular}




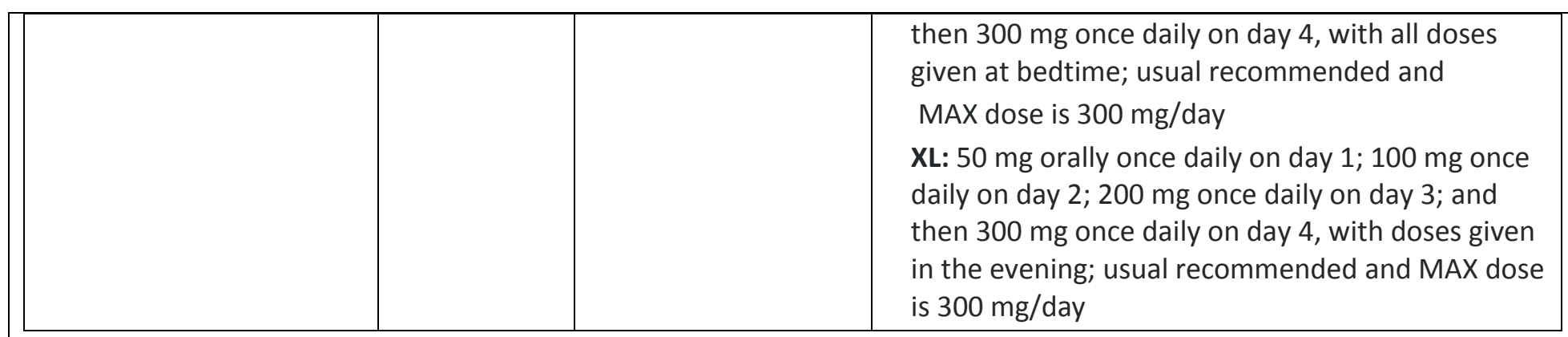

\section{Bipolar disorder with chronic diseases}

\begin{tabular}{|c|c|c|c|}
\hline Condition & Dose & Therapy & Comments \\
\hline \multirow{3}{*}{$\begin{array}{l}\text { Diabetes or } \\
\text { High cholesterol level \& } \\
\text { Cardiovascular disease }\end{array}$} & $1 \ldots \ldots \ldots \ldots$ & Aripiprazole & $\begin{array}{l}\text { Starting dose } 10-15 \mathrm{mg} \text {, Maintenance dose } 10-15 \mathrm{mg} \text {, } \\
\text { Maximum dose } 30 \mathrm{mg} \text { once daily OR }\end{array}$ \\
\hline & $2 \ldots \ldots \ldots \ldots$ & Lamotrigine & $\begin{array}{l}200 \mathrm{mg} / \text { day }(100 \mathrm{mg} / \text { day in patients taking } \\
\text { valproate OR }\end{array}$ \\
\hline & $3 \ldots \ldots \ldots$ & Valproate & $\begin{array}{l}\text { IR: } 250 \mathrm{mg} / \text { day three times a day increasing } \\
\text { according to tolerability \& plasma levels, max. dose } \\
\text { (15-30mg/kg/day) } \\
\mathrm{XL}: 500 \mathrm{mg} / \text { day increasing as above. } \\
\text { Max. dose }(20-30 \mathrm{mg} / \mathrm{kg} / \text { day) }\end{array}$ \\
\hline \multirow[t]{3}{*}{ Renal impairment } & $1 \ldots \ldots \ldots \ldots$ & Valproate & \multirow{3}{*}{$\begin{array}{l}\text { Start at low dose and increase slowly, monitor for } \\
\text { adverse effects }\end{array}$} \\
\hline & $2 \ldots \ldots \ldots$ & Carbamazepine & \\
\hline & $3 \ldots \ldots \ldots \ldots \ldots$ & Lamotrigine & \\
\hline Hepatic impairment & $\cdots \cdots \cdot$ & lithium & $\begin{array}{l}\text { Use plasma levels to guide dosage. Care needed if } \\
\text { ascites status changes }\end{array}$ \\
\hline
\end{tabular}

NOTES :

Physician/Clinical Pharmacist Name:

pager:

Physician/Clinical Pharmacist signature:

Nurse name:

Nurse signature:

\section{References:}

1. Taylor D, Paton C, Kapur S, South London and Maudsley NHS Trust. The Maudsley prescribing guidelines in psychiatry [Internet]. Wiley-Blackwell; 2015 [cited 2018 Apr 19]. 760 p. Available from: https://www.wiley.com/ensa/The+Maudsley+Prescribing+Guidelines+in+Psychiatry,+12th+Edition-p-9781118754603

2. Hirschfeld RM a. Guideline Watch : Practice Guideline for the Treatment of Patients With Bipolar Disorder, 2Nd Edition. Practice [Internet]. 2005;(November):1-9. Available from: http://www.argos2001.org/APA-2005-Bipolar-watch.pdf

3. Bowden CL, Gitlin MJ, Keck PE, Suppes T, Ph D. Treatment of Patients With Bipolar Disorder Second Edition. APA Prat Guidel. 2010;(December):1-82.

4. UpToDate ${ }^{\circledR}$ [Internet]. 2018 [cited 2018 Apr 19]. Available from: https://www.uptodate.com/contents/search

5. Micromedex [Internet]. 2018 [cited 2018 Apr 19]. Available from: http://www.micromedexsolutions.com/micromedex2/librarian 